2006-01-01

\title{
Managing fisheries resources in Kaptai reservoir, Bangladesh
}

\author{
Ahmed, KKU
}

http://hdl.handle.net/10026.1/4029

$10.5367 / 000000006779398281$

Outlook on Agriculture

SAGE Publications

All content in PEARL is protected by copyright law. Author manuscripts are made available in accordance with publisher policies. Please cite only the published version using the details provided on the item record or document. In the absence of an open licence (e.g. Creative Commons), permissions for further reuse of content should be sought from the publisher or author. 


\title{
Managing fisheries resources in Kaptai reservoir, Bangladesh
}

\author{
Khan Kamal Uddin Ahmed, Sanzidur Rahman \\ and Saleh Uddin Ahammed
}

\begin{abstract}
This paper examines the various challenges facing the development of fisheries resources in Kaptai reservoir, Bangladesh. The reservoir has undergone major changes in its catch composition since impoundment. Production records show a declining trend in the productivity of high-value fish. A host of managerial, socioeconomic and environmental factors are responsible for the underutilization of the reservoir's potential to provide high-value freshwater fish. These include deterioration of the natural breeding ground, environmental damage, poor implementation of regulations, inefficient fish farming technology and poor management practices. These constraints are discussed and possibilities for future improvements are suggested.
\end{abstract}

Keywords: reservoir fishery; management policy; Bangladesh

Khan Kamal Uddin Ahmed is a Senior Scientific Officer with the Bangladesh Fisheries Research Institute, Riverine Station, Chandpur-3602, Bangladesh. Sanzidur Rahman is a Principal Lecturer in Rural Development with the School of Geography, Faculty of Social Science and Business, University of Plymouth, Plymouth PL4 8AA, UK. Tel: +44 1752 238411. Fax: +44 1752 233054. E-mail: srahman@plymouth.ac.uk. Saleh Uddin Ahammed is Chief Scientific Officer with the Bangladesh Fisheries Research Institute, Riverine Station, Chandpur-3602, Bangladesh.

The Kaptai reservoir in Bangladesh, one of the largest man-made freshwater reservoirs in South-east Asia (Fernando, 1980), was created in 1961 by damming the River Karnaphuli at Kaptai, mainly to provide electricity by hydropower. Fisheries, flood control, drainage and irrigation, plus navigation, were considered as secondary options. The reservoir covers an area of approximately 58,300 ha $(68,800$ ha at full supply level) and constitutes a significant component of inland water resources accounting for $46.8 \%$ of the total pond area of Bangladesh (Ahmed, 1999). It thus offers huge potential for fish production, a priority source of protein in the Bangladeshi diet. The present contribution from this fishery is around 6,000 mt per annum, with high annual fluctuation (Ahmed et al, 2001). The performance of the Kaptai reservoir suffers from a host of environmental, socioeconomic and management constraints affecting its potential. A considerable number of people living in surrounding areas depend on this reservoir for their livelihood. Despite its great socioeconomic value, past work on the Kaptai reservoir focused on biological and limnological aspects of the fisheries (for example, Ahmed et al, 1994; Hye and Alamgir, 1992; ARG, 1986; Azadi, 1985; Chowdhury and Mazumdar, 1981), with limited studies on its socioeconomic aspects (for example, Haldar et al, 2003; Ahmed, 1999; Hye, 1988).

Given this background, we undertake a critical analysis of the current status of the Kaptai reservoir, highlight various constraints affecting its development as an important source of high-value freshwater fishery, and discuss the potential for improvements. The study is based on the analysis of information and data generated by the Bangladesh Fisheries Research Institute, Riverine Sub-Station (BFRI-RSS) and reviews of work published by different authors and by the Bangladesh Fisheries Development Corporation (BFDC), which has been responsible for managing the reservoir since 1963.

\section{Trends in fish production, productivity and composition}

A total of 73 fish species belonging to 47 genera, 25 families, two species of prawn and one species of dolphin have been identified so far (Ahmed, 1999). Of these, 31 
species have commercial importance, but their contribution to total landings is not significant due to changes in the physical environment. Over the years, eight species of fish have totally disappeared, seven species are dwindling, seven new species were introduced and 11 species, mainly clupeids, have become dominant in the reservoir (Ahmed, 1999).

Records of landings at the BFDC-managed pontoon show that the production of fish from this reservoir grew at an estimated annual rate of $3.5 \%$ from the first harvest in 1966 to 2001 (Figure 1). The average annual landing was 3,530 $\mathrm{mt}$, with large variations between years. The maximum production of $6,586 \mathrm{mt}$ was obtained in 1998, mainly due to an explosive growth in clupeids. But this production does not include fish caught for local consumption and pilferage to avoid royalty payments to BFDC. Estimates of such unrecorded fish range from 30\% (ARG, 1986) to 40-50\% (BFRI-RSS, 2000).

The productivity record for 1987-2001 reveals that fish yields increased at an annual rate of $3.8 \%$ (Figure 2 ). The mean yield was estimated at $81.5 \mathrm{~kg} / \mathrm{ha}$, with large variations over time. The yield increases to $105.9 \mathrm{~kg} / \mathrm{ha}$ when an estimated $30 \%$ of unrecorded fish is added. The reservoir can thus be classified as moderately productive when compared with its peers in Asia, for example, in Thailand (Bhukaswan and Chookajorn, 1988), Indonesia (Baluyut, 1985) and India (Sharma, 1988).

Carp ${ }^{1}$ used to be the predominant species in the early years post-impoundment, but these gave way to clupeids ${ }^{2}$ (a marine-derived fish). Carp contributed $81.4 \%$ of the total landing during the first harvest in 1966 (Figure 1)

The yield of carp steadily declined from $19 \mathrm{~kg} / \mathrm{ha}$ during the 1970s to only $5 \mathrm{~kg} / \mathrm{ha}$ in the 1990s, and now contributes only $5.1 \%$ of total landings. On the other hand, the current yield of clupeids is $32 \mathrm{~kg} / \mathrm{ha}$. Among the clupeids, three pelagic species, Corica soborna, Gudusia chapra and Gonialosa manminna accounted for $63.4 \%$ of the total catch in 2001, making up the highest contributing group, growing at an annual rate of $8.7 \%$ over the past 14 years (Figure 2). Dried fish ${ }^{3}$ also contribute $28.3 \%$ of total landing, of which clupeids constitute $80 \%$ of the total weight. Similar explosive growth of clupeids (eg Corica goniognatus) was found in Thai reservoirs (eg Sirikit, Sirinthorn and Lampao) making a significant contribution (Pawaputanon, 1986). Fernando and Holcik (1991) and Fernando (1998) noted that, in addition to lacustrine fish, marine-derived fish, eg clupeids, osmerids and some other families, had colonized many reservoirs in recent years.

\section{Environmental, management and socioeconomic issues}

The world's lakes suffer from one or more of the following seven major threats: (i) accelerated eutrophication; (ii) invasive species; (iii) toxic contamination; (iv) overfishing; (v) water diversion; (vi) acidification; and (vii) climate change (Borre et al, 2001). Therefore, the main management challenge is to devise strategies that can effectively address most or all of these threats.

The Kaptai reservoir seems to suffer to a large extent from three of these seven major threats: (i) invasive species (eg the explosive growth of clupeids) - a key environmental constraint, (ii) overfishing of certain species - a common socioeconomic constraint, and (iii) water diversion, mainly to regulate electricity - a classic management constraint.

\section{Environmental issues and constraints}

Ecological changes. Great ecological changes were observed in the reservoir ecosystem turning from acidic to neutral (Chowdhury and Mazumdar, 1981) and then to alkaline, with a pH level of 9.00 (BFRI-RSS, 2000). Based on the analysis of dissolved oxygen content, total hardness and $\mathrm{pH}$ level of the water, Kaptai reservoir can be regarded as medium-productive, with the overall water quality deemed to be suitable for improved fisheries. A key physical constraint of the Kaptai reservoir is the great fluctuation in water level due to the 'rule curve' set by Kaptai Hydro Power Station (KHPS) to regulate electricity supply. Further loss of water occurs through irrigation, and half of the reservoir surface area dries out for at least three months of the year. High water turbidity is also a remarkable feature of Kaptai reservoir, caused mainly by soil erosion.

Primary production. Based on the analysis of primary production and fish yield in relation to gross synthesis and plankton biomass, the estimated potential production of Kaptai could reach between 19,000 and 26,000 mt, whereas actual average production stands at only $6,000 \mathrm{mt}$ per year, with high annual fluctuations. Factors responsible for such variation include the productivity of the reservoir, the number of fishermen, fishing techniques and management policy. In general, shallow reservoirs with wide fluctuations achieve high fish production, with high yields occurring one year after high water level (Bhukaswan and Pholprasith, 1976).

Natural breeding. Natural breeding is the main source of auto-stocking of a water body. Among the 73 species of fishes in the Kaptai reservoir, most breed naturally. But the majority of carp tend not to breed in confined water, although they can mature there. Several attempts were made to explore the breeding grounds of major carp species of the Kaptai reservoir, and four suspected spawning sites were identified during the mid-1980s (Azadi, 1985; ARG, 1986). BFRI-RSS (2000) suspects that natural spawning has not occurred successfully for the important carp species since the 1990s. Siltation due to shifting cultivation, high water level fluctuation, lack of rainfall and thunder showers at breeding time are assumed to be the more important causes, but low current velocity during the breeding season and fishing pressure are also suspected (Ahmed, 1999).

Exotic species. Since the 1980s, BFDC has used some exotic species in its stocking programme, but subsequent landings of these species have not been satisfactory. However, this has not always been the case for introduced species. Following its accidental introduction in 1985, the controversial exotic fish, Nile Tilapia (Oreochromis niloticus), established itself successfully and currently contributes $3 \%$ to the total catch. Tilapia replaced all species including Gangetic carp in the Vaigai reservoir, and seriously altered the native species spectrum, ultimately bringing down production in the Amravati, 


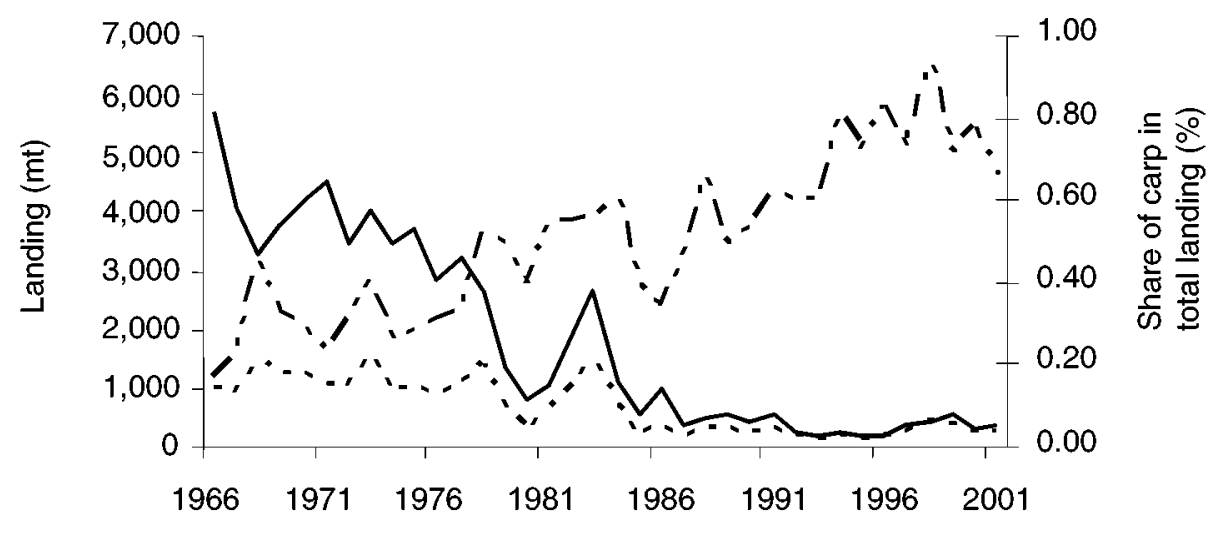

\begin{tabular}{|l|r|r|r|r|r|}
\hline \multicolumn{1}{c|}{} & \multicolumn{3}{c|}{ Share } \\
\cline { 2 - 6 } \multicolumn{1}{c|}{ Mean landing } & Std dev & Minimum & Maximum & Growth rate \\
\hline Carp & 665.64 & 468.53 & 93.95 & $1,635.12$ & -0.0773 \\
\hline Total fish & $3,530.44$ & $1,363.33$ & $1,206.63$ & $6,586.31$ & 0.0347 \\
\hline
\end{tabular}

Figure 1. Trends in fish production in Kaptai reservoir (1966-2001).

Note: Growth rates are estimated using semi-log trend function: $\ln Y=\alpha+\beta T$, where $T$ denotes time and $\beta$ is the growth rate.
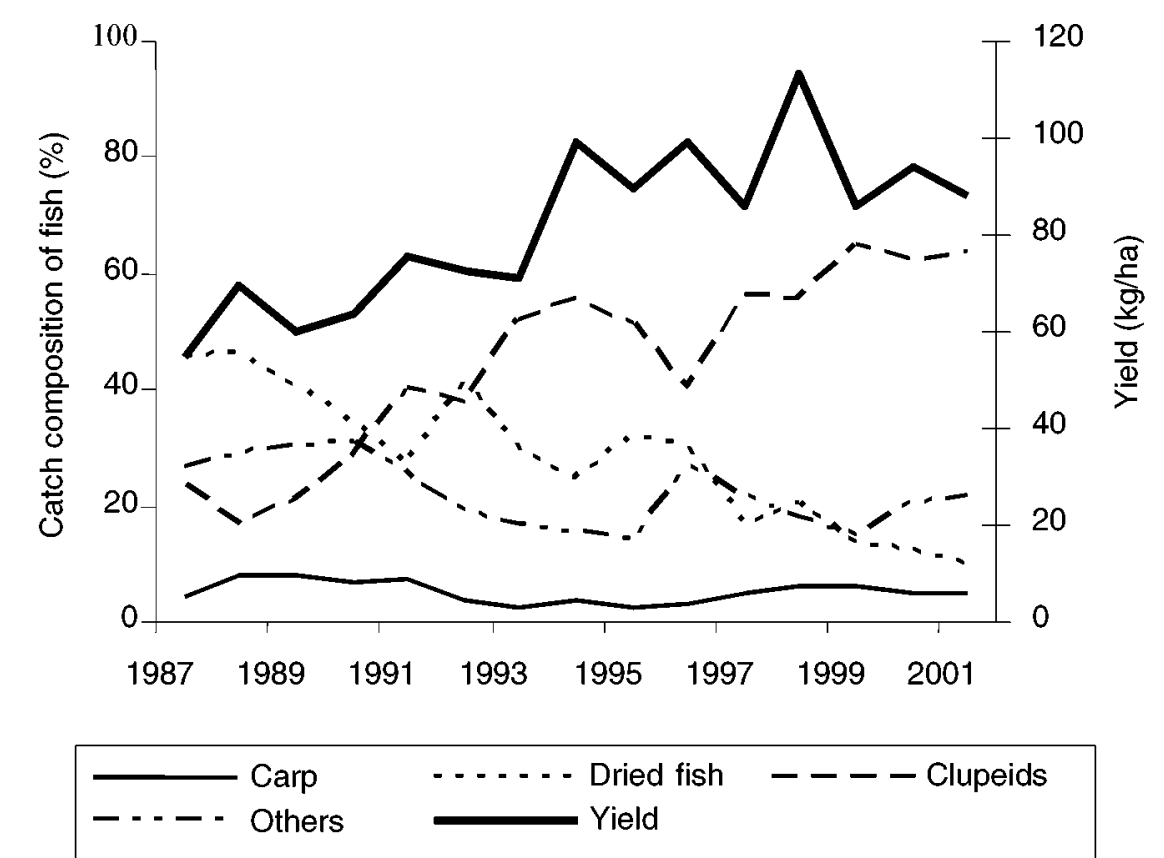

\begin{tabular}{|l|c|c|c|c|c|}
\hline & Mean & Std dev & Minimum & Maximum & Growth rate \\
\hline Yield (kg/ha) & 81.49 & 16.51 & 54.56 & 112.98 & 0.0376 \\
\hline $\begin{array}{l}\text { Catch } \\
\text { composition }\end{array}$ & & & & & \\
\hline Carp & 5.11 & 1.99 & 2.20 & 8.27 & -0.0203 \\
\hline Dried fish & 28.33 & 11.97 & 9.95 & 46.12 & -0.1001 \\
\hline Clupeids & 44.54 & 16.27 & 16.60 & 64.92 & 0.0873 \\
\hline Others & 22.10 & 5.73 & 14.38 & 30.71 & -0.0330 \\
\hline
\end{tabular}

Figure 2. Trends in fish yield and catch composition in Kaptai reservoir (1987-2001).

Note: Growth rates are estimated using semi-log trend function: $\ln Y=\alpha+\beta T$, where $T$ denotes time and $\beta$ is the growth rate. 
Sathanur and Powai reservoirs of India (Jhingran, 1992). Introduction of Nile perch (Lates niloticus) in Lake Victoria boosted the fishing industries of Uganda, Kenya and Tanzania at the cost of extinction of 200 fish species (Ntiba et al, 2001). ARG (1986) cautioned that Tilapia might compete with native carp for food and survival in the Kaptai reservoir, which may now be the case.

\section{Management issues and constraints}

Fishing in the Kaptai reservoir was leased in 1963 for 99 years to BFDC, which has landing station, ice plant and refrigeration facilities. The management of the Kaptai reservoir fisheries basically pertains to: (a) restricting fishing to certain periods, (b) issuing licences to the fishermen, (c) implementing the Fisheries Act, and (d) using the most advocated and widely practised stocking and recapture techniques.

Licensing and royalty payments. Provision for licensing was initiated in 1972 by BFDC, and gear licensing started in 1981. Only licensed fishermen are allowed in the reservoir, but when compliance was checked through a survey, only $29 \%$ of the fishermen had fishing licences (Ahmed, 1999). The government loses approximately BDT420,000 (US\$7,200) per year from licence fees alone. Sometimes fish traders pay the licence fee on behalf of fishermen, who are then obliged to sell all their catch to the traders at ex-vessel price, which is $55 \%$ to $125 \%$ lower than the prices in local and city markets. BFDC collects royalties in cash ranging from $33-40 \%$ of the total fish landing, depending on species. High rates are imposed for high-priced and big fish, thereby encouraging fish pilferage.

Stocking and fishing pressure. Fishing at the Kaptai reservoir was banned for the first three years after its construction, and 2.3 million carp fry were stocked to build up a readily available population. Since then, BFDC has liberated about $30 \mathrm{mt}$ of fingerlings each year, but without signs of any success. During 1981-85, 1.6 million exotic carp fingerlings were stocked to colonize vacant/ new ecological niches and to utilize aquatic weeds in the reservoir. Commercial landings from these three exotic species during 1983-88 were only $3.17 \mathrm{mt}$, showing unsuccessful recruitment. Stocking of carp fingerlings in the past did not follow any particular numbers or species composition. From 1990 onward, a stocking programme was implemented using a predetermined number of selfsustainable sized $(9-13 \mathrm{~cm})$ fingerlings with a given species composition. But repopulation has not occurred at all, possibly because of the long journeys to which fingerlings are subjected after being procured nearly $200 \mathrm{~km}$ away from the reservoir, causing injury and infection, the short time for acclimatization, lack of proper handling of fingerlings, lack of therapeutic measures, high water depth and possible inbreeding effects, since the fingerlings are procured from the same sources every year. Evidence of an inbreeding effect on stocked fish was found when they were cultured in pens installed in creeks at the Kaptai reservoir (Ahmed et al, 2002). Also, the use of fishing gear such as hooks and lines and brush shelters catch a significant proportion of fingerlings during the post-stocking period (Ahmed and Hambrey, 1999). Thus far, however, funds spent on stocking the Kaptai reservoir have been lower than the value of recaptured fish. The earnings grew at a rate of $16.8 \%$, while expenses grew at a rate of $13.3 \%$ per year (Figure 3 ).

Studies on population dynamics and assessment of stock of any fishery are of great importance in management. Thus far, fishing pressure on only five commercially important species in the Kaptai reservoir have been analysed. The results show that two species (L. rohita and C. Mrigala) are under high fishing pressure, C. catla is under optimum fishing pressure and L. calbasu and O. niloticus are under lower fishing pressure. Therefore, any major change in the existing exploitation of the first three species will hamper maximum sustainable yield potential and call for the imposition of fishing regulation.

Fishing prohibitions in closed period and fish harvesting target. Fishing in the Kaptai reservoir remains closed from mid-June to mid-September. Commercial exploitation usually stops (almost, if not fully) during this period, but subsistence fishermen and tribal people continue to catch fish for home consumption and illegal marketing. Also, in remote areas of the reservoir, imposition of a complete fishing ban is impossible. Artificial stocking is performed during the closed period to protect fingerlings, but remains unsuccessful due to reasons cited above. Sometimes, the start of the closure period is delayed to fulfil the fish harvesting targets set annually by BFDC, which unfortunately are not based on any factual data or scientific background (ARG, 1986). Jenkins (1985) concluded that the harvest of the major carp species might have exceeded the maximum sustainable level due to the setting of such targets. Since the 1980s, the carp fishery seems to have been overexploited and no larger-sized mother stocks are left for autostocking or subsequent breeding. Also, from the very beginning, fishing continued without following any particular regulation, but mainly to fulfil only the harvesting target.

Minimum size of fish harvest and mesh size regulation. In the Kaptai reservoir, C. catla weighing less than $2.0 \mathrm{~kg}$, L. rohita $<1.0 \mathrm{~kg}$, C. mrigala $<0.75 \mathrm{~kg}$ and L. calbasu $<0.5 \mathrm{~kg}$, cannot be landed, although this is not strictly imposed. The legal minimum permissible mesh size for gill nets is $7.62 \mathrm{~cm}$, but it is not followed by fishermen because too many clupeids are not captured by this mesh size, leading to poor catches, and fishermen, knowing the leniency of enforcement, resort to much smaller mesh sizes.

Reservoir level and rule curve. The mean water level fluctuation of the Kaptai reservoir is 8.14 m (ARG, 1986). KHPS follows a rule curve to maintain this level, but this is difficult in practice because of the irregular rainfall. It is interesting to note that the water level of the Kaptai reservoir has been maintained at lower levels during breeding seasons (June-August) since the start, even though this is detrimental to natural breeding success. Fluctuation of water level and heavy shoreline siltation were identified as major causes of the gradual disappearance of fish species and destruction of natural breeding grounds in the Lewis and Clarke lakes in the USA (Walburg, 1976).

Administrative bottleneck. Four institutions with conflicting roles are involved in administering this 


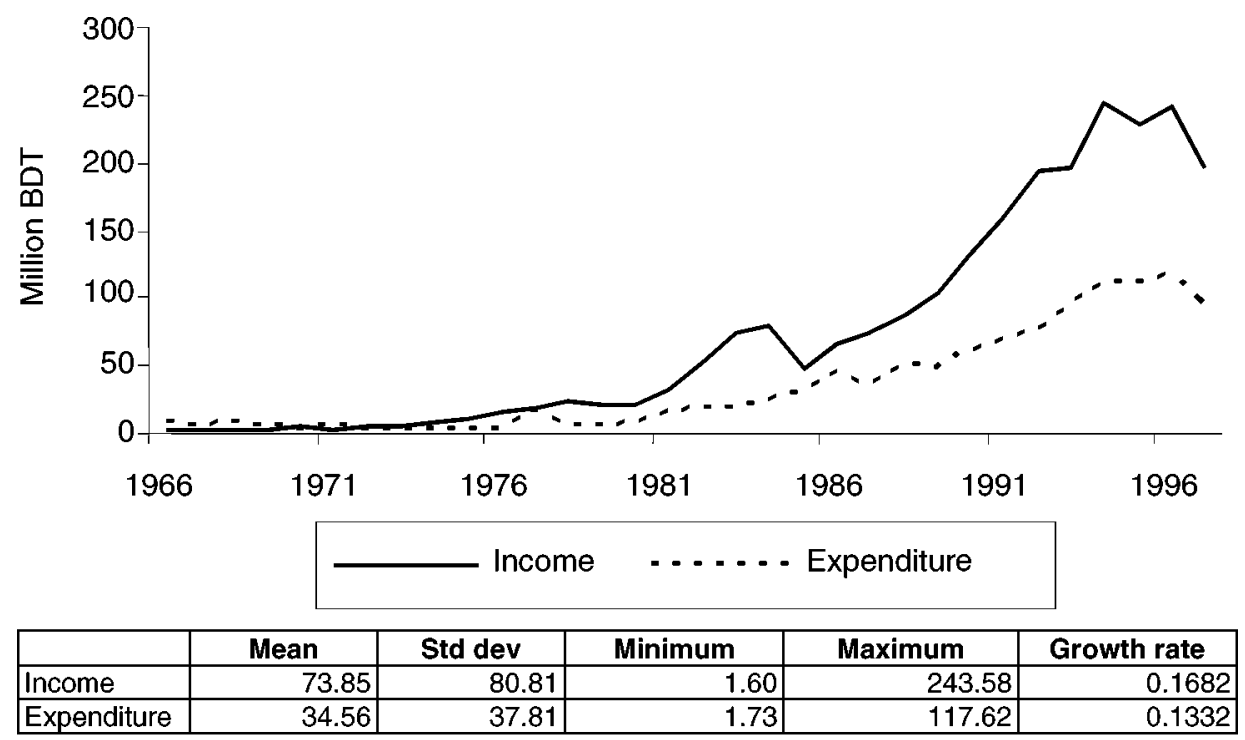

Figure 3. Trends in expenditure and earnings from Kaptai reservoir, from BFDC.

Note: Growth rates are estimated using semi-log trend function: $\ln \gamma=\alpha+\beta T$, where $T$ denotes time and $\beta$ is the growth rate.

reservoir. BFDC is responsible for overall management and is concerned with commercial exploitation of fish, marketing, declaration of closed season, licensing, stocking and guarding. BFRI provides research and technical support. However, the Department of Fishery (DoF) coordinates all extension and conservation activities, except management, and is responsible for implementing the Fish Act, eg ban on undersized fish harvest, mesh size regulation, licence checks and monitoring the closed season. On the other hand, the Civil Administration (Deputy Commissioner) is responsible for final decision making and enforcement of regulations concerning conservation and utilization of natural resources. In other words, the institution responsible for management of the reservoir is not equipped with enforcement capabilities, and vice versa, thereby resulting in classic poor enforcement of regulations. Furthermore, the Rangamati field units of these institutions are poorly equipped, understaffed and underfunded, all coupled with inadequate logistic support and physical infrastructure.

\section{Socioeconomic issues and stakeholders' constraints}

In addition to BFDC, DoF, BFRI and the Civil Administration, two other major stakeholders are the fishermen themselves and the fish traders, whose socioeconomic circumstances, customs and practices significantly affect the performance of this fishery. For instance, the number and types of craft and gear used in fishing, as well as the method and timing of fishing, have important implications for stocking success and fish yield. Some of the key issues are discussed below.

Fishing craft and diversified fishing gear. Two types of fishing craft, the large country boat (10-12 m length, 1$2 \mathrm{~m}$ breadth) and small country boat (6-8 m length, $0.7-1.2 \mathrm{~m}$ breadth) are commonly found in the Kaptai reservoir. The former is generally used for seine netting and operated by 5-10 fishermen, while the latter is used for other fishing gear and operated by 1-2 fishermen. Occasionally, the tribal people use boats made by hollowing out a large timber log. All these craft are made of indigenous timbers and are rowed manually. Only the carrier boats operated by fish traders are mechanized.

Fishing operations in the Kaptai reservoir were first started in January 1963 by small groups of fishermen with only three types of gear, namely: seine nets, gill nets, and hooks and lines (Mesbahuddin, 1966). However, a wider range of fishing gear is now in use (Figure 4). In recent years, a shift in gear operation was observed. With the appearance of clupeids since 1980, a large number of very small-meshed mosquito nets (beach seine) came into use, and these are on the rise. A four-boat lift net is a new introduction, which consists of a net of four mesh sizes arranged vertically to catch different sizes of fish at one time. An unusual but very destructive fishing method, known locally as 'brush shelter' (a fish attraction device) has also been in operation in the reservoir since early 1990, and an estimated 1,000 brush shelters are in operation (Ahmed, 1999). BFRI-RSS (1993) estimated that there were 679 gill nets, 305 seine nets, 93 lift nets, 18 push nets and 212 hooks and lines of different categories in use.

Role of fishers and fish traders. Three categories of fishermen are involved in fishing in the Kaptai reservoir: (a) owners of boats and gear who are economically solvent; (b) owners of boats and gear who operate with loans from fish traders; and (c) fishing labour who are hired either on a daily or monthly basis by (a) and (b). Both local residents and immigrant fishermen are found on the Kaptai reservoir. About $38 \%$ of the owner fishermen accompanied by fishing labour come from different districts of Bangladesh to the Kaptai reservoir during the fishing season, and play a vital role in commercial exploitation, since local fishermen are resource-poor and 


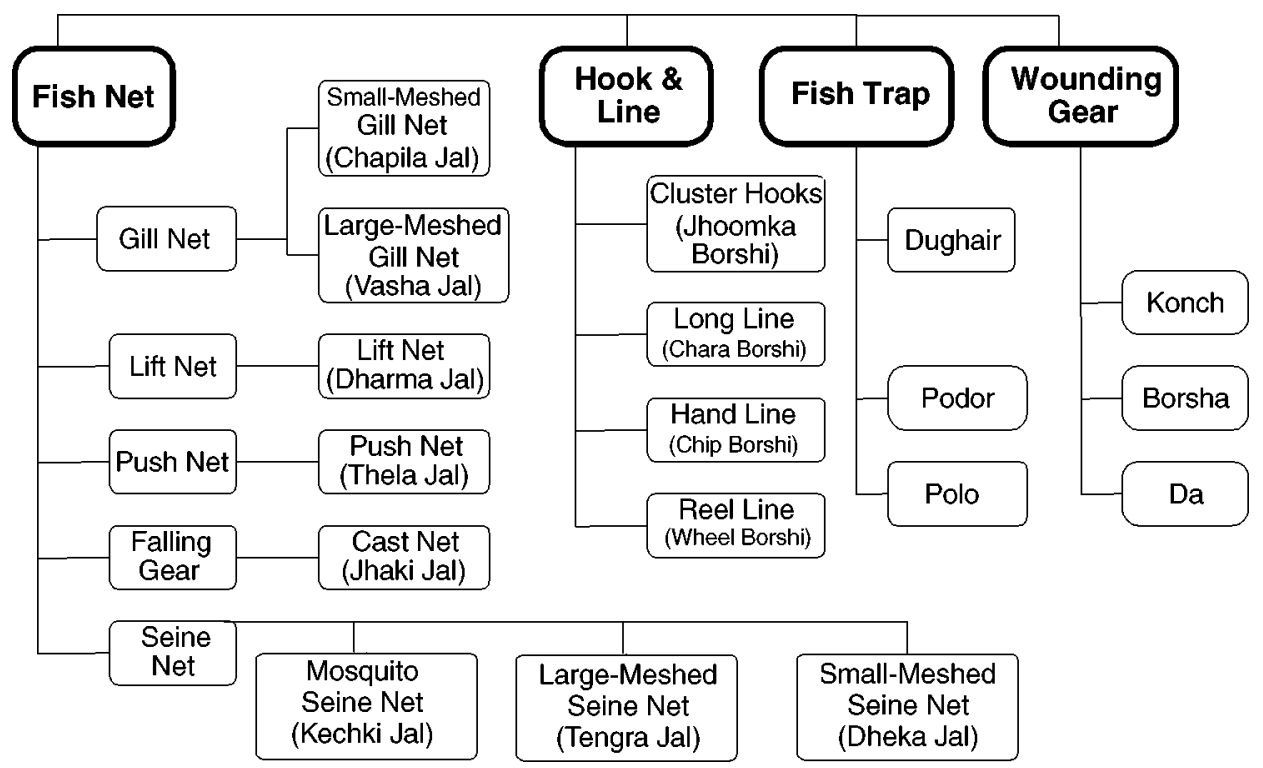

Figure 4. Classification of the fishing gear employed in the Kaptai reservoir. Note: after Ahmed, 1999.

are engaged in subsistence fishing only. An estimated 5,560 fishers are engaged in fishing in the Kaptai reservoir (Ahmed, 1999).

Fish traders and private entrepreneurs conduct all fishing and marketing activities, except the fish harvest and provision of infrastructure. BFDC issues licences to fish traders at very low fees. Currently, 185 fish traders (compared with only seven in the early years) regulate the fish trade in the Kaptai reservoir. Of these, 30 traders (called master traders) handle the lion's share of commercial landing and control most fishermen tied through loan disbursements (Ahmed, 1999). There are about 52 local markets along the reservoir, which are free from BFDC royalties when unrecorded fish are sold.

\section{Potential for improvement}

Since reservoirs are created artificially by flooding a given habitat, some environmental changes over the maturation process are inevitable. For instance, changes occur in the species composition from riverine species (such as carp) to small pelagic species (such as clupeids) over time. The reservoir area was once part of the undulating valleys and lower reaches of the Karnaphuli River and its four streams and, therefore, is now strewn with submerged wooden logs and hillocks, as the area was not cleared prior to impoundment. Decay of flooded vegetation and natural decline of the productivity of the changing water environment may also be responsible for the poor productivity of this fishery. The loss of natural breeding grounds of carp may be partly due to the fact that the natural floodplain habitat in which carps previously bred has been inundated or lost since impoundment. Nevertheless, apart from these natural and irreversible causes, other most likely causes of failure to improve the production potential of the Kaptai reservoir are ineffectiveness in implementing existing regulations and prioritizing needs, failure to plan stocking programmes and setting unrealistic harvesting targets. Also an essential element, the legislative policy framework for protection and conservation of aquatic resources of the Kaptai reservoir is lacking and should be addressed urgently.

An integrated approach to reservoir management is essential to improve the productivity of this reservoir. One of the key principles will be to ensure the involvement of key stakeholders who are most affected by management decisions, particularly the resource-poor fishermen whose livelihoods depend on this reservoir. Community-based fisheries management (CBFM) is a possible solution for promoting fisheries on the inland floodplains of Bangladesh, and this has been tested with support from the World Fish Centre, international donor agencies, local non-governmental organizations (NGOs) and local community organizations since 1996. Although the results were mixed, the following important lessons emerged:

(1) it is essential that communities obtain rights over the fisheries;

(2) strong facilitation is necessary;

(3) taking up visible resource management practices helps greatly;

(4) success is more likely in homogeneous communities; and

(5) effective, well defined partnerships between NGOs and government (although difficult to establish) were sufficiently beneficial (Thompson et al, 2003).

Similar CBFM schemes could be a viable option for managing the Kaptai reservoir and should receive serious consideration. Also, sound management practice should be based on scientific evidence and factual data. To this end, surveys to generate information on the number of 
craft and type of gear used, mode of use, numbers of fishermen involved, catch per unit of effort, fish composition and species diversity, can be conducted at least every five years. The potential for future improvements in other key areas is discussed below.

\section{Stocking management}

The usual solution to counter loss of natural breeding grounds is artificial stocking, which is followed in the Kaptai, but with the caveats discussed above. A tripartite coordination between three main agencies, DoF, BFRI and BFDC could initiate the production of self-sustained fingerlings within or along the reservoir area, thereby avoiding the transportation of fingerlings over long distances, which entails various disadvantages. The ongoing programme of BFRI-RSS offers this potential. The management should also be aware of the inbreeding effect resulting from artificial stocking. Stocking of hatcheryreared and other non-native fish can dilute the gene pool of the indigenous population if not managed properly. For example, hatchery-reared steelhead trout (Salma gairdneri) were less successful in reproducing naturally than wild fish (Chilcote et al, 1986). Continuous monitoring and supervision of hatchery activities can ensure the quality of fish seed. Two months of precautionary measures in the nursery grounds of supplemental stocking could substantially reduce natural and fishing mortality. At least $20 \%$ of fingerlings should ideally come from natural sources, which points towards the need to develop natural spawning grounds upstream of the reservoir. Keeping the water at the optimum level during the spawning season would require strong interagency coordination between BFDC, BFRI, DoF and KHPS. In Cuba, a well organized network of fish seed production centres caters for the stock requirements of all state-controlled reservoir fisheries (Sugunan, 1997).

\section{Effective implementation of fishing regulations}

Effective implementation of existing fishing regulations, such as licensing, mesh size, legal catch size, approved gear, and fishing ban period, must be ensured. This can be achieved by a major overhaul in defining the roles and responsibilities of key agencies (BFDC, BFRI, DoF and the Civil Administration) under a common policy framework avoiding existing contradictory management structures. Enforcement of actions should also be based on realistic fees and proper service provision from the authorities in return for these charges. Zoning of fishing areas, together with the establishment of additional landing units and realistic fishing royalties, may go some way to reducing pilferage. To protect the fish, fishing ban periods should start from early May and should be effectively implemented if gravid broods in migration channels are to be protected and breeding performance assured. In Thailand, the use of high-efficiency fishing gear in freshwater is prohibited from 16 May to 15 September, the spawning season of freshwater fishes. Fishing is also prohibited in rivers for a distance of $3 \mathrm{~km}$ downstream from the dam to protect migratory species (Bhukaswan and Chookajorn, 1988). However, such compliance will only be feasible with the active participation of all key stakeholders, including fishermen, through active consultation, planning and consensus, a key feature of
CBFM. A BFDC target-oriented production plan should be avoided. Also, gear approval is essential. On the basis of known stock, fishing licences for different gear should be issued for particular stocks, and fishermen should be discouraged from the use of gill nets, brush shelters and hooks and lines by raising awareness of the long-term effects of such practices. For example, use of gill nets in rivers is categorically prohibited in Zimbabwe, and a licence is required for manufacturing, storing, buying or selling them (Sugunan, 1997). Such an all-round policy is likely to be more successful than banning only the use of certain gear. Existing regulations on legal harvesting size of carp need effective implementation, and fishermen should be penalized when these are breached.

\section{Research and development (RED)}

Need-based research on the management and production of the Kaptai reservoir could be undertaken with a collaborative effort between BFRI and BFDC. New technologies to increase production could be another major research focus. For example, preliminary results from a 3-year collaborative study by BFRI-RSS and BFDC indicated that polyculture of Indian carp and Chinese carp in pens installed in creeks/coves, constructed by fencing off constricted openings with small-meshed nets, might be a unique system to enhance fish production in the reservoir. Several creek sites along the reservoir watershed were identified where pen installation would be possible. The average retrieval rate of stocked carp was $24.4 \%$ (range $6.5-38.5 \%$ ). The average yield from the creeks was $966.0 \mathrm{~kg} / \mathrm{ha}$, nine times higher than the natural catch $( \pm 110 \mathrm{~kg} / \mathrm{ha})$ from the reservoir. The economic and ecological significance of creek aquaculture has not yet been completely assessed, and deserves more experiments as well as assessment of the risks involved with such techniques. However, if proved successful, this approach could improve productivity and generate income and employment. Adaptation of the cage culture technique also exhibited promising results with respect to adaptability and survivability. Research is in progress for further technology development at BFRI. Also, it was found that nursing spawn was possible in the creek environment during lean periods. More experiments are required to identify a suitable technology package for this option. This technique might be an excellent way of raising fingerlings within the reservoir environment, which could reduce the fingerling procurement costs of BFDC, as well as mortality.

\section{Building partnerships, community participation and extension}

The involvement of local fishermen in raising stocking materials may create an avenue by which to establish a congenial environment for the success of supplemental stocking programmes. Periodic training for fishermen on the Fish Act and fishing regulations can be arranged during fishing ban periods. Fish sanctuaries should be declared in which there will be restricted year-round fishing around each known spawning and nursery ground. However, this can be implemented effectively only with community participation and consensus. Awareness of building programmes can be initiated with the use of common extension techniques such as 
distribution of leaflets, booklets, posters, and using mass media for sustainable management of the reservoir.

\section{Marketing and infrastructure support}

In recent years, some Indian states have created public sector fisheries corporations, which follow a system of harvest sharing, whereby fishermen give a share of their catch to the government as a royalty of $25-50 \%$, depending on reservoir productivity. In return, the government supplies boats, nets and all other fishing equipment (Sugunan, 1997). The Kaptai reservoir management might consider the value of such a practice.

Direct market intervention to increase low ex-vessel price could prove difficult. In India, market intervention attempts made in the past by state governments did not produce the desired results (Sugunan, 1997). However, facilitating institutional sources of loans could serve the purpose by freeing the fishermen from ties to fish traders. Building fisheries cooperatives of local fishermen could be a viable option that would enable them to compete with migrant commercial fishermen who appear not to have any commitment to conserving the resources of the Kaptai reservoir. Also, to ensure the quality of the fish harvested, ice for refrigeration should be made widely available in various locations around the reservoir by establishing more ice plants, currently a responsibility of BFDC.

\section{Conclusion}

This paper has provided a detailed analysis of the various challenges affecting development of the Kaptai reservoir as a rich, high-value fishery. Apart from natural and environmental constraints, a host of managerial and socioeconomic issues are affecting the performance of this reservoir. Nevertheless, there remains the potential for improvement. It is to be hoped that the results of this study will help in devising appropriate management strategies to develop the full production potential of the Kaptai reservoir fisheries.

\section{Notes}

1 These are members of the Cyprinidae (Labeo rohita, Catla catla, Cirrhinus mrigala and Labeo calbasu).

2 These are members of the Clupeidae (Corica soborna, Gudusia chapra and Gonialosa manminna).

3 Dried fish is a heterogeneous assemblage of short-lived, easily caught, small or moderate-sized, low-priced fish of all categories.

\section{References}

Ahmed, K. K. (1999), 'Options for the management of major carp fishery in the Kaptai Reservoir, Bangladesh', PhD dissertation, School of Environment, Resources and Development, Asian Institute of Technology, Bangkok.

Ahmed, K. K., Alamgir, M., and Haldar, G. C. (2002), 'Pen fish culture in lake-valley as a new production system of Kaptai Reservoir, Bangladesh', in Islam, Z, ed, Proceedings of the $2^{\text {nd }}$ ANR Agricultural Conference, ICMH, Matuail, Dhaka, Bangladesh, pp $120-126$

Ahmed, K. K., Haldar, G. C., Saha, S. B., and Paul, S. K. (1994),

'Studies on the primary production in Kaptai Reservoir',

Bangladesh Journal of Zoology, Vol 22, pp 69-77.
Ahmed, K. K., and Hambrey, J. B. (1999), 'Brush shelter: a recently introduced fishing method in the Kaptai Reservoir fisheries in Bangladesh', NAGA ICLARM Quarterly, Vol 22, pp 20-23.

Ahmed, K. K., Hambrey, J. B., and Rahman, S. (2001), 'Trends in inter-annual yield variation of reservoir fisheries in Bangladesh with special reference to Major Carps', Lakes and Reservoirs: Research and Management, Vol 6, pp 85-94.

ARG - Aquatic Research Group (1986), Hydrobiology of Kaptai Reservoir, FAO/UNDP Final Report No. DP/BGD/79/015-4/FI, University of Chittagong, Bangladesh.

Azadi, M. A. (1985), 'Hydrological conditions influencing the spawning of major carps in the Halda river, Chittagong, Bangladesh', Bangladesh Journal of Zoology, Vol 13, pp 163-172.

Baluyut, E. A. (1985), 'Planning for inland fisheries under constraints from other uses of land and water resource; general considerations and the Philippines', FAO Fisheries Circular, FAO, Rome.

BFRI-RSS (1993), 'Population dynamics and stock assessment studies on Kaptai Lake', Progress Report (1991-1992), BFRI-RSS, Rangamati, Bangladesh.

BFRI-RSS (2000), 'Studies of production potentiality and management of fisheries of Kaptai Lake', Annual Progress Report (1999-2000), BFRI-RSS, Rangamati, Bangladesh.

Bhukaswan, T., and Chookajorn, T. (1988), 'Reservoir fisheries management in Thailand', in De-Silva, S. S., ed, Reservoir Fishery Management and Development in Asia, Proceedings of a workshop held in Kathmandu, Nepal, 23-28 November 1987 IDRC-264e, Ottawa, pp 154-157.

Bhukaswan, T., and Pholprasith, S. (1976), 'The fisheries of Ubolratana Reservoir in the first ten years of impoundment', Technical Paper No. 16, Freshwater Fisheries Division, Department of Fisheries, Bangkok.

Borre, L., Barker, D. R., and Duker, L. E. (2001), 'Institutional arrangements for managing the great lakes of the world: results of a workshop on implementing the watershed approach', Lakes and Reservoirs: Research and Management, Vol 6, pp 199-209.

Chilcote, M. W., Leider, S. A., and Loch, J. J. (1986), 'Differential reproductive success of hatchery and wild summer-run steelhead under natural conditions', Transactions of the American Fisheries Society, Vol 115, pp 726-735.

Chowdhury, S. C., and Mazumdar, A. (1981), 'Limnology of Lake Kaptai - 1: physico-chemical features', Bangladesh Journal of Zoology, Vol 9, pp 59-72.

Fernando, C. H. (1980), 'The fishery potential of man made lakes in South East Asia and some strategies for its optimization', in BIOTROP Anniversary Publication, Bogor, Indonesia, pp 23-28.

Fernando, C. H. (1998), Lacustrine Fishes and Their Role in Asian Reservoirs, Department of Biology, University of Waterloo, Ontario.

Fernando, C. H., and Holcik, J. (1991), 'Fish in reservoirs', International Review of Hydrobiology, Vol 76, pp 149-167.

Haldar, G. C., Ahmed, K. K., Alamgir, M., Akhter, J. N., and Rahman, M. K. (2003), 'Fisheries of Kaptai Reservoir, Bangladesh', in Cowx, I. G., ed, Management and Ecology of Lake and Reservoir Fisheries, Fishing News Books, Blackwell Science, Oxford, pp 144-158.

Hye, M. A. (1988), 'Socio-economic condition of Kaptai Lake fisherman', Bangladesh Journal of Extension Education, Vol 3, pp 23-33.

Hye, M. A., and Alamgir, M. (1992), 'Investigation on the natural spawning of carps in Lake Kaptai', Bangladesh Journal of Zoology, Vol 20, pp 27-33.

Jenkins, R. M. (1985), Final Report on the Planning, Implementation and Follow-Up of Fishery Management of Kaptai Lake, Aquatic Research Group, University of Chittagong, Bangladesh.

Jhingran, A. G. (1992), 'Recent advances in reservoir fisheries management in India', in De Silva, S. S., ed, Reservoir Fisheries of Asia, Proceedings of the 2nd Asian Reservoir Fisheries Workshop, IDRC-Ottawa, Ontario, pp 158-175.

Mesbahuddin, M. (1966), 'Limnology of Karnafuli reservoir and fish production' (mimeo), BFRI-RSS, Rangamati, Bangladesh. 
Ntiba, M. J., Kudoja, W. M., and Mukasa, C. T. (2001), 'Management issues in the Lake Victoria watershed', Lakes and Reservoirs: Research and Management, Vol 6, pp 211-216.

Pawaputanon, O. (1986), 'Fisheries and fishery management of large reservoirs in Thailand', in Maclean, J. L., Dizon, L. B., and Hosillos, L. V., eds, The First Asian Fisheries Forum, Asian Fisheries Society, Manila, pp 389-392.

Sandercook, F. K. (1966), Chittagong Hill Tracts Soil and Land Use Survey, Volume 4: Fisheries (Canadian Colombo Plan Project F-475), East Pakistan Agricultural Development Corporation, Karachi.

Sharma, R. C. (1988), 'Aims and strategies of fisheries management for the Tehri Dam Reservoir in the Garhwal Himalaya, India', in De Silva, S. S., ed, Reservoir Fishery Management and
Development in Asia, Proceedings of a workshop held in Kathmandu, Nepal, 23-28 November 1987, IDRC, Ottawa, Ontario, IDRC - 264e, pp 145-153.

Sugunan, V. V. (1997), 'Fisheries management of small water bodies in seven countries in Africa, Asia and Latin America', FAO Fisheries Circular No. 933, FAO, Rome.

Thompson, P. M., Sultana, P., and Islam, N. (2003), 'Lessons from community based management of floodplain fisheries in Bangladesh', Journal of Environmental Management, Vol 69, pp 307-321.

Walburg, C. H. (1976), 'Changes in the fish population of Lewis and Clark lake, 1956-1974, and their relation to water management and the environment', Research Report No. 79, US Fish and Wildlife Service, Washington, DC. 